\title{
Quinoa Flour as a New Foodstuff for Improving Dough and Bread
}

\author{
Naofumi Morita, ${ }^{*}$ Chikako Hirata, Sang Ha Park and Toshio Mitsunaga ${ }^{1}$ \\ Laboratory of Food Chemistry, Graduate School of Agriculture and Biological Sciences, \\ Osaka Prefecture University (1-1, Gakuencho, Sakai 599-8531, Japan) \\ ${ }^{1}$ Department of Food and Nutrition, Faculty of Agriculture and Institute for Comprehensive Agriculture, \\ Kinki University (3327-204, Nakamachi, Nara 631-8505, Japan)
}

\begin{abstract}
Characteristics of dough and bread containing quinoa flour as a new foodstuff were studied using a rheometer, a farinograph, differential scanning calorimeter (DSC) and so on. Substitution of 7.5 to $10 \%$ of quinoa flour for hard-type wheat flour significantly increased the loaf volume of bread over that of the control, but more than $15 \%$ substitution distinctly decreased the volume. However, a combination of microbial lipase $(75 \mathrm{ppm})$ and $15 \%$ substitution of quinoa flour resulted in a loaf volume that was distinctly more than that of the control. The hardness of bread crumbs increased in proportion to the amount of quinoa flour substitution. Combining the quinoa flour with lipase suppressed the staling of bread during storage and maintained softness by the liberation of monoglyceride from lipids. DSC data showed that substitution of quinoa flour resulted in a distinctly higher gelatinization temperature and gelatinization enthalpy compared with that of the control. As for the viscoelastic properties of the dough, combining quinoa flour (5 to $10 \%$ substitution) and lipase $(75 \mathrm{ppm})$ resulted in reduction of compression stress and the modulus of elasticity, a slight softening of the dough, and slight decreases in the water absorption and the stability of the dough. From these results, a combination of quinoa flour substitution and lipase addition was found to improve bread qualities.
\end{abstract}

About three thousand species of edible plants in total have been cultivated in the past history of mankind. However, most of them have gradually disappeared, and only a total of 30 species remain in the world. ${ }^{1)}$ The criteria of the continuation of species might not be due to the quality of crops, but to the yield of production, to the special climate requirement for the production, to the crops cultivated by small communities or tribes, and so on. As the result, plants yielding quite high amounts of crops, such as rice, wheat, corn, etc. are selected in the area of sub-tropical or tropical countries.

Quinoa, one of the pseudocereals, belongs to an annual plant of Chenopodium, which is mainly produced in the highland of Peru and Bolivia, and the grain contains large amounts of minerals, lipids, and high quality protein, which contain abun- dant essential amino acids, such as lysine or histidine. $^{2,3)}$ Therefore, the amino acid score of the flour is higher than the scores of rice, wheat and corn. Quinoa flour is rarely allergenic and also the outer layer of the grain lowers the cholesterol level of blood. ${ }^{4)}$ Furthermore, NASA has recommended quinoa as one of the plants that are suitable for CELSS (controlled ecological life support system), which can reduce $\mathrm{CO}_{2}$ concentration in a manned spacecraft atmosphere, and produce foodstuffs, oxygen and water. From these points of view, we focused our attention on using quinoa flour as wheat flour substitute and microbial lipase for a bread improver. This study deals with the effect of quinoa flour substitution on some rheological properties of wheat flour dough and on the loaf volume of bread.

\footnotetext{
* To whom correspondence should be addressed.
} 


\section{MATERIALS AND METHODS}

Flour and chemicals. The wheat flour used for bread making was a hard-type "Camelia" (Nisshin Flour Milling Co., Ltd., Kobe) as described previously. ${ }^{5}$ "The protein and ash contents were $13.6 \%$ and $0.44 \%$, respectively, on a dry flour basis.

Quinoa flour (Chenopodium quinoa Real) was obtained from Asai Co., Ltd. (Nagoya), which had imported it from Peru. The flour contained 14.9\% protein, $75.1 \%$ starch, $5.5 \%$ lipids, $2.4 \%$ fiber, $2.1 \%$ ash on a dry flour basis. The crude lipase $\left(7.5 \times 10^{3} \mathrm{U} / \mathrm{g}\right)$ of Aspergillus niger was provided by Amano Pharmaceutical Co., Ltd. (Nagoya). The enzyme contained negligible amount of protease and about $5 \times 10^{-2} \mathrm{U}$ of amylase per one unit of lipase. But, the amylase was heat-unstable and did not degrade the raw starch distinctly during the mixing and breadmaking process. The amount of lipase used was $75 \mathrm{ppm}$ on a flour basis. Grain fatty acid methyl ester-mixture was purchased from Suppelco (USA). Other chemicals used were of analytical grade.

Bread baking. The bread making formula was $280 \mathrm{~g}$ of flour, $5 \mathrm{~g}$ of sodium chloride, $17 \mathrm{~g}$ of sucrose, $3 \mathrm{~g}$ of dry baker's yeast (Asahi Kasei, Co., Ltd., Tokyo), and $210 \mathrm{~g}$ of water in the presence or absence of additives.

Test loaves were baked with five automatic bread makers in the same manner described previously. ${ }^{6}$ The total time for the entire process was 4 $\mathrm{h}$ (20 min mixing, $10 \mathrm{~min}$ aging, $10 \mathrm{~min}$ additional mixing after addition of yeast, $155 \mathrm{~min}$ fermentation and $45 \mathrm{~min}$ baking). The volumes of loaves were measured by the rapeseed displacement method.

Data were analyzed by using statistical analysis of variance (ANOVA), and Duncan's multiplerange test was used to compare treatment means; differences among samples were considered significant at $p<0.05$.

\section{Analytical methods.}

Rheological tests. Farinograms were recorded in a Brabender Farinograph equipped with a $300 \mathrm{~g}$ stainless steel bowl. The standard speed of mixing was $63 \mathrm{rpm}$ at $30^{\circ} \mathrm{C}$. The farinograph data including the percentage of water absorption, arrival time, development time, and stability time were obtained on maximum resistance, centered on 500 B.U.

Viscoelastic properties of the dough and the bread crumbs were measured using a Fudoh rheometer (Rheotech Co., Ltd., Tokyo), as described previously. ${ }^{5)}$ For the dough sample which was obtained by mixing for $30 \mathrm{~min}$ in the home baker, a $1-\mathrm{cm}$ diameter plunger for viscoelastic measurement and a $3-\mathrm{cm}$ i.d. $\times 5 \mathrm{~cm}$ sample were used, and the penetration depth was controlled at 2 $\mathrm{cm}$. On the other hand, for the bread crumbs, a 3$\mathrm{cm}$ diameter plunger for compression stress and a $4 \times 4 \times 3 \mathrm{~cm}^{3}$ sample of stale bread was used, and the compression depth was controlled at $7 \mathrm{~mm}$. For both samples, the speed of the plunger was 6 $\mathrm{cm} / \mathrm{min}$, and the data were processed using a computer program, Rheosoft TR-06 (Rheotech Co., Ltd., Tokyo).

\section{Differential scanning calorimetry (DSC).} DSC was taken with a Shimadzu DSC instrument (Model DSC-50, Tokyo) as described previously, ${ }^{5,7)}$ with liquid paraffin as a reference. The initial temperature $\left(T_{\mathrm{i}}\right)$, peak temperature $\left(T_{\mathrm{p}}\right)$ and recovery temperature $\left(T_{\mathrm{r}}\right)$ of gelatinization of starch and melting of starch-lipid complex, and enthalpy values for starch $\left(\Delta h_{1}\right)$ and starch-lipid complex $\left(\Delta h_{2}\right)$ were measured to characterize the thermal properties of dough. The temperature was raised from room temperature to $120^{\circ} \mathrm{C}$ at the rate of $5^{\circ} \mathrm{C} /$ $\min$.

Scanning electron microscopy (SEM). SEM in a Hitachi SEM apparatus (Model S-800) was essentially the same as described previously. ${ }^{6}$

Image analysis of crumb grains. The procedure was the same as reported previously, ${ }^{5)}$ using a Pias Computer Image Analyzer PIAS LA555 equipped with a CCD camera PX-380 and a Victor color monitor AV-M150S. Xerox photocopies of bread crumbs $\left(7 \times 7 \mathrm{~cm}^{2}\right)$ were placed under a nonreflective holding mask, and cell size information was stored in the computer memory. For an analysis of the mean diameter of gas cells, a $6 \times 6-\mathrm{cm}^{2}$ area in the middle part of a slice was used. A group of pixels of more than $0.0308 \mathrm{~mm}^{2}$ was 


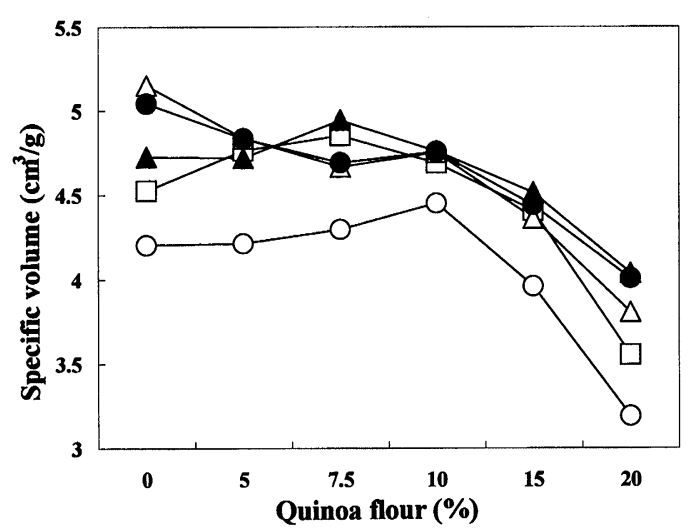

Fig. 1. Effect of lipase on specific volume of bread substituted with quinoa flour.

Amount of lipase (ppm/g flour basis) $: \bigcirc, 0 ; \square, 50 ; \boldsymbol{\Delta}$, 75; $\triangle, 100 ; \bigcirc, 200 .(N=3)$

counted as one gas cell, and the data were processed as the area-equivalent diameter when gas cells were assumed to be a circle.

Gas-liquid chromatography (GLC). GLC was carried out with a Yanagimoto GCG-equipped with a flame ionization detector, fitted with a glass column $(0.34 \mathrm{~cm}$ i.d. $\times 2 \mathrm{~m})$ packed with $3 \%$ DEGS on Chromosorb WAW DMCS (80-100 mesh) (GL Sciences Inc., Tokyo). Analytical conditions were as follows: The column was programmed at a rate of $5^{\circ} \mathrm{C} / \mathrm{min}$ from $160^{\circ} \mathrm{C}$ to 210 ${ }^{\circ} \mathrm{C}$; the detector and injector, $250^{\circ} \mathrm{C} ; \mathrm{N}_{2}$ gas was at a flow rate of $2.1 \mathrm{~cm}^{3} / \mathrm{min}$. Free lipids extracted from lyophilized dough sample using $n$-hexane was methylated for 5 min with BF3 in methanol, as reported. ${ }^{8.9)}$ An aliquot of lauric acid was used for an internal standard.

\section{RESULTS AND DISCUSSION}

\section{Baking results.}

Substitution of $7.5 \%$ and $10 \%$ of quinoa flour for wheat flour increased the loaf volume of bread significantly compared with that of the control without quinoa flour (Fig. 1). This suggests that substitution of quinoa flour improves the balance of starch, protein and lipids. Fifteen percent or more of replacement with quinoa flour resulted in a distinct decrease in the loaf volume. Addition of lipase alone to the ingredients increased the spe-
Table 1. Average diameter of gas cells of bread baked with quinoa flour substitution.

\begin{tabular}{ccc}
\hline $\begin{array}{c}\text { Quinoa flour } \\
(\%)\end{array}$ & $\begin{array}{c}\text { Lipase 0 } \\
(\mathrm{ppm})\end{array}$ & $\begin{array}{c}\text { Lipase 75 } \\
(\mathrm{ppm})\end{array}$ \\
\hline 0 & $1.16 \pm 0.01$ & $0.99 \pm 0.04$ \\
5.0 & $1.04 \pm 0.01$ & $0.99 \pm 0.16$ \\
7.5 & $0.88 \pm 0.07$ & $0.97 \pm 0.24$ \\
10.0 & $1.04 \pm 0.13$ & $1.10 \pm 0.03$ \\
15.0 & $1.07 \pm 0.15$ & $1.17 \pm 0.11$ \\
20.0 & $1.07 \pm 0.23$ & $1.09 \pm 0.06$ \\
\hline
\end{tabular}

Number of experiment: 3. Each value shows in $\mathrm{mm}$.

cific volume of bread in proportion to the amount of lipase tested. Combinations of $7.5 \%$ quinoa flour substitution and $50 \mathrm{ppm}$ or $75 \mathrm{ppm}$ lipase addition increased the loaf volume significantly as compared with the control.

Table 1 shows the average diameter of the gas cells of bread baked with various amounts of quinoa flour. Substitution of $7.5 \%$ quinoa flour with $(0.97 \pm 0.24 \mathrm{~mm})$ or without $(0.88 \pm 0.07 \mathrm{~mm}) 75$ ppm lipase showed the lowest diameter of gas cells.

Figure 2 shows the change of firmness of bread crumbs during storage at $25^{\circ} \mathrm{C}$ in a wrapped vessel. In the bread crumbs baked with various amounts of quinoa flour substitution without addition of lipase, the firmness was proportional to the amount of quinoa flour substitution and number of storage days. Addition of $50 \mathrm{ppm}$ lipase to various amounts of quinoa flour distinctly suppressed the firmness as compared with the control. The suppression of firmness was obvious at $15 \%$ or more of quinoa flour substitution containing $50 \mathrm{ppm}$ or more of lipase. Therefore, staling of bread crumbs was obviously improved by use of lipase.

As a result, substitution of about $7.5 \%$ quinoa flour for wheat flour improved the specific volume and gas cell distribution of the bread. Also, addition of lipase improved the staling of bread crumbs during storage.

\section{Dough property.}

The viscoelastic properties, such as relaxation time, stress, modulus of elasticity, and viscosity coefficient of wheat dough containing various amounts of quinoa flour was measured using a 


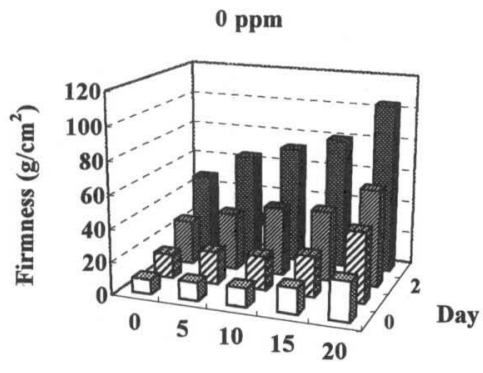

Quinoa flour (\%)

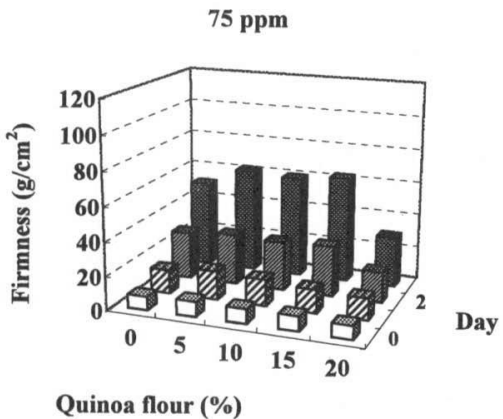

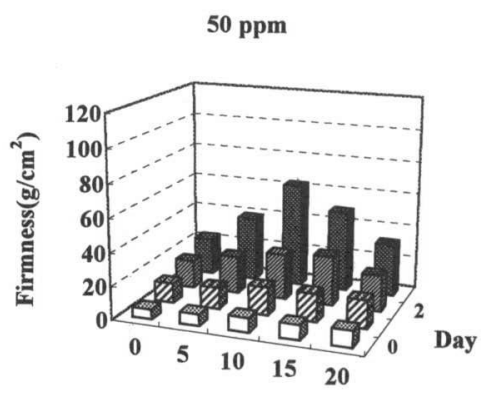

Quinoa flour (\%)

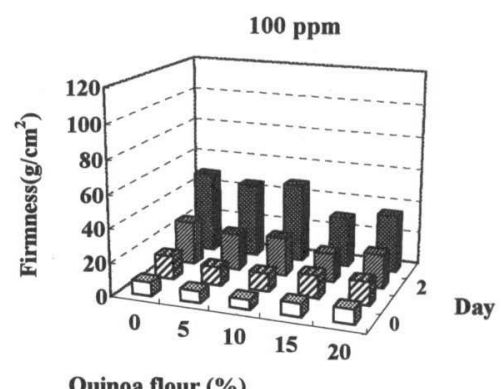

Quinoa flour (\%)

Fig. 2. Staling of bread crumbs baked with various amounts of quinoa flour containing lipase, as measured by a rheometer. $(N=3)$

Table 2. Viscoelastic properties of dough substituted with quinoa flour.

\begin{tabular}{ccccc}
\hline $\begin{array}{c}\text { Quinoa flour } \\
(\%)\end{array}$ & $\begin{array}{c}\text { Relaxation time } \\
(\mathrm{s})\end{array}$ & $\begin{array}{c}\text { Stress } \\
\left(10^{2} \mathrm{~N} / \mathrm{m}^{2}\right)\end{array}$ & $\begin{array}{c}\text { Modulus of elasticity } \\
\left(10^{4} \mathrm{~N} / \mathrm{m}^{2}\right)\end{array}$ & $\begin{array}{c}\text { Viscosity coefficient } \\
\left(10^{4} \mathrm{~N} \cdot \mathrm{s} / \mathrm{m}^{2}\right)\end{array}$ \\
\hline 0 & 0.6 & $101.4 \pm 6.9$ & $4.39 \pm 0.25$ & $2.63 \pm 0.11$ \\
5.0 & 0.7 & $103.6 \pm 1.2$ & $4.54 \pm 0.11$ & $2.86 \pm 0.11$ \\
7.5 & 0.6 & $113.8 \pm 12.4$ & $5.12 \pm 0.27$ & $3.07 \pm 0.20$ \\
10.0 & 0.6 & $125.1 \pm 13.1$ & $5.63 \pm 0.32$ & $3.65 \pm 0.21$ \\
15.0 & 0.6 & $121.6 \pm 3.4$ & $5.09 \pm 0.17$ & $3.01 \pm 0.24$ \\
\hline
\end{tabular}

Number of experiment: 3 .

rheometer. As is obvious from Table 2, the relaxation time did not change, but the other parameters were the highest in the case of $10 \%$ quinoa flour substitution when compared with the control or other amounts of quinoa flour substitution. The addition of $75 \mathrm{ppm}$ lipase to the same dough also showed a result similar to that without lipase addition. This increase may be caused by the strengthening effect of the gluten network or dough structure. However, in the case of $15 \%$ quinoa flour substitution, the stress, elasticity and viscosity coefficient of the dough was reduced distinctly. This result is surely due to the decrease in the amount of glutenin and gliadin in the dough, and the subsequent decrease in the amount of gluten forma- tion. Furthermore, addition of lipase might increase the amounts of monoglyceride and/or free fatty acids, and the monoglycerides produced could act as an emulsifier. This would then result in clear decreases in the elasticity and viscosity coefficient.

Figure 3 shows the farinograph data of quinoa flour-substituted wheat dough, including the arrival time, development time of dough, stability of dough, and water absorption. The values of the farinograph parameters, except for the arrival time, decreased distinctly in proportion to the amount of quinoa flour substitution, suggesting that quinoa flour substitution changes the consistency of the dough. In case of 75 ppm lipase addition, all pa- 
Lipase 0 ppm

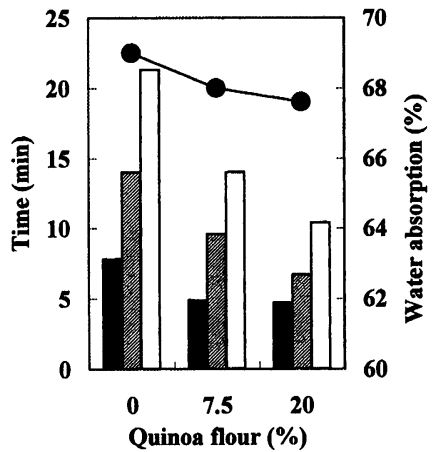

Lipase 75 ppm

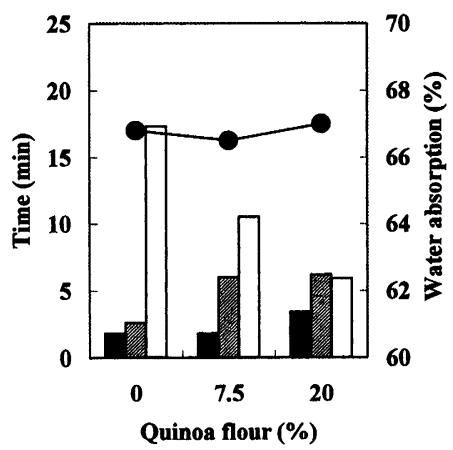

Fig. 3. Properties of doughs, as measured by a farinograph.

$\square$, arrival time; development time; $\square$, stability time; $\bigcirc$, water absorption. $N=2$.

Table 3. Effect of quinoa flour and lipase concentration on thermal properties of dough.

\begin{tabular}{ccccccc}
\hline $\begin{array}{c}\text { Quinoa flour } \\
(\%)\end{array}$ & $\begin{array}{c}\text { Lipase } \\
(\mathrm{ppm})\end{array}$ & $\begin{array}{c}T_{\mathrm{i}} \\
\left({ }^{\circ} \mathrm{C}\right)\end{array}$ & $\begin{array}{c}T_{\mathrm{p}} \\
\left({ }^{\circ} \mathrm{C}\right)\end{array}$ & $\begin{array}{c}T_{\mathrm{r}} \\
\left({ }^{\circ} \mathrm{C}\right)\end{array}$ & $\begin{array}{c}\Delta h_{1} \\
(\mathrm{~J} / \mathrm{g})\end{array}$ & $\begin{array}{c}\Delta h_{2} \\
(\mathrm{~J} / \mathrm{g})\end{array}$ \\
\hline 0 & 0 & 57.7 & 63.7 & 90.7 & 2.68 & 1.05 \\
0 & 75 & 58.7 & 65.5 & 89.9 & 3.22 & 1.00 \\
7.5 & 0 & 58.4 & 64.9 & 87.9 & 1.92 & 1.13 \\
7.5 & 75 & 59.2 & 66.1 & 87.4 & 2.26 & 1.00 \\
20 & 0 & 58.5 & 66.7 & 87.2 & 1.76 & 1.30 \\
20 & 75 & 59.8 & 66.8 & 86.3 & 1.97 & 1.46 \\
100 & 0 & 60.2 & 67.4 & 83.3 & 2.13 & 1.34 \\
\hline
\end{tabular}

Number of experiment: 2 .

rameters tested became lower than the control without lipase. In particular, lipase addition resulted in a distinctly shorter development time compared with that of the control without lipase addition. Furthermore, the development time of dough increased in proportion to the amount of quinoa flour substitution.

Thermal properties of starch in dough substituted with quinoa flour.

Table 3 shows the results of thermal properties of dough after mixing for $30 \mathrm{~min}$ using DSC. Regardless of the addition of lipase, $T_{\mathrm{i}}$ and $T_{\mathrm{p}}$ of the dough increased and $T_{\mathrm{r}}$ decreased slightly, according to the increase in the quinoa flour substitution. The value of $\Delta h_{1}$ decreased in proportion to the increase in the quinoa flour substitution, while that of $\Delta h_{2}$ increased. The addition of quinoa flour did not improve the favorable gluten formation, but rather deteriorated the formation (as is obvious from Fig. 4-B and C). Therefore, the gluten sheet surrounding the starch granules was assumed to weaken the dough strength with the addition of quinoa flour. However, the gelatinization temperature of starch in dough increased slightly. This fact may be mainly caused by the presence of quinoa flour having a higher gelatinization temperature $\left(67.4^{\circ} \mathrm{C}\right)$ and lower gelatinization enthalpy $(2.13 \mathrm{~J} /$ g) than those of wheat flour. In general, the $\Delta h_{2}$ peak is considered to be derived from lipid-starch complex. $\left.{ }^{10}\right)$ But, $\Delta h_{2}$ was normally smaller in the case of wheat dough than $\Delta h_{1}$. And also the quinoa starch, having a high water swelling power, ${ }^{11}$ may increase the water binding-capacity of the substituted dough. The present quinoa flour increased $\Delta h_{2}$, which might be caused by the formation of starch-lipid complexes; therefore suppression of the staling of bread crumbs was expected. However, no distinct relations between the firmness of bread crumbs baked with 5 or $10 \%$ quinoa 

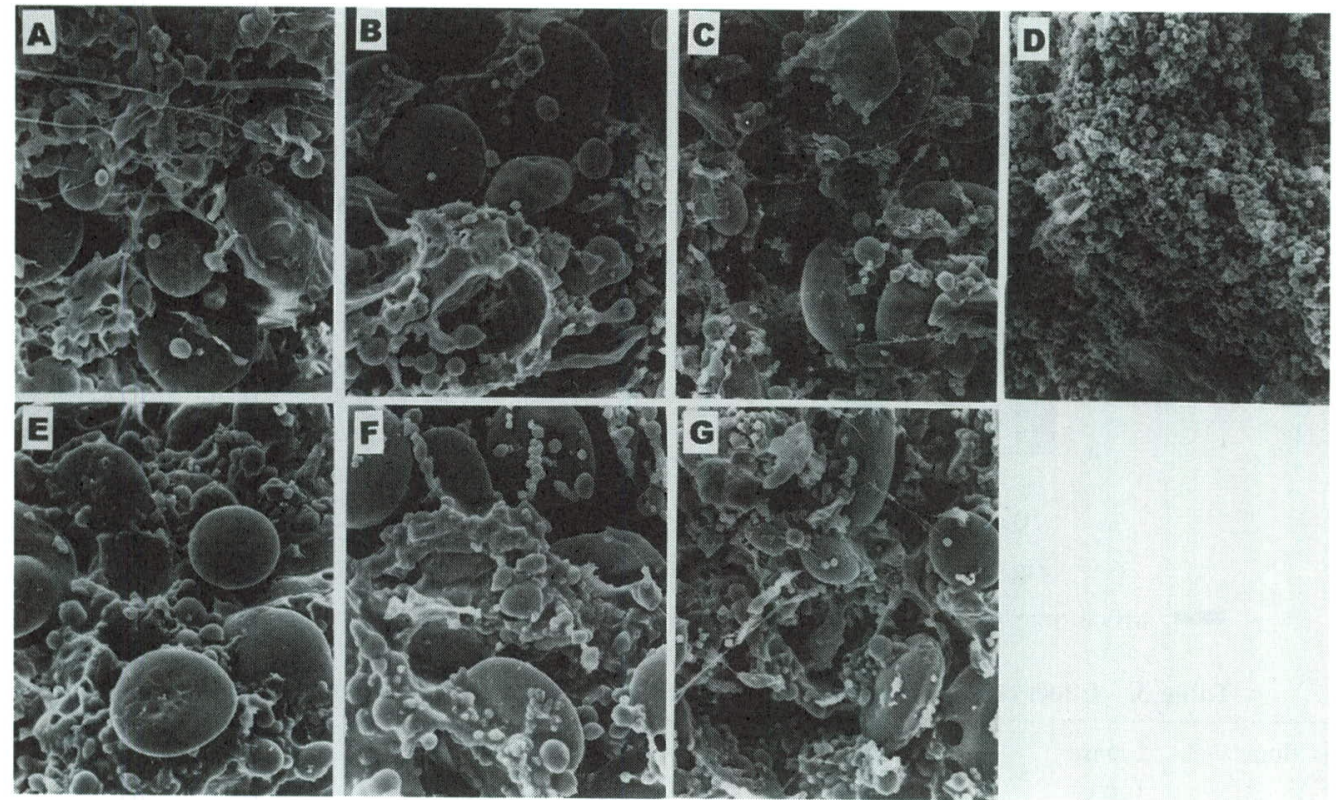

Fig. 4. SEM photographs of doughs containing various amounts of quinoa flour with or without lipase.

Quinoa flour substitution: A, quinoa flour $0 \%$; B, quinoa flour 7.5\%; C, quinoa flour 20\%; D, quinoa flour $100 \%$. The lower line (E, F, and G) contains 75 ppm of lipase. Direct magnification, $\times 1500$.

Table 4. Composition of free fatty acid in dough containing various amounts of quinoa flour with or without lipase.

\begin{tabular}{|c|c|c|c|c|c|c|c|c|}
\hline \multirow{3}{*}{$\begin{array}{l}\text { Lipase (ppm) } \\
\text { Quinoa flour (\%) } \\
\text { Time (min) }\end{array}$} & \multicolumn{4}{|c|}{0} & \multicolumn{4}{|c|}{75} \\
\hline & \multicolumn{2}{|c|}{0} & \multicolumn{2}{|c|}{7.5} & \multicolumn{2}{|c|}{0} & \multicolumn{2}{|c|}{7.5} \\
\hline & 20 & 195 & 20 & 195 & 20 & 195 & 20 & 195 \\
\hline C14:0 & 0.03 & 0.07 & 0.12 & 0.05 & 0.03 & 0.06 & 0.04 & 0.04 \\
\hline C16:0 & 0.29 & 0.57 & 1.54 & 0.69 & 0.38 & 0.35 & 0.70 & 0.53 \\
\hline C18:0 & 0.03 & 0.07 & 0.11 & 0.05 & 0.02 & 0.05 & 0.04 & 0.04 \\
\hline C18:1 & 0.25 & 0.46 & 1.52 & 0.99 & 0.30 & 0.27 & 1.02 & 0.78 \\
\hline C18:2 & 0.83 & 1.59 & 5.28 & 2.46 & 1.09 & 0.98 & 2.58 & 1.98 \\
\hline C18:3 & 0.05 & 0.10 & 0.40 & 0.30 & 0.06 & 0.06 & 0.34 & 0.24 \\
\hline C20:0 & - & - & - & 0.02 & - & - & 0.01 & - \\
\hline $\mathrm{C} 22: 0$ & - & - & - & 0.03 & - & - & 0.01 & - \\
\hline $\mathrm{C} 22: 1$ & - & - & - & 0.01 & - & - & 0.03 & 0.02 \\
\hline Total & 1.48 & 2.86 & 8.97 & 4.60 & 1.88 & 1.77 & 4.77 & 3.63 \\
\hline
\end{tabular}

Each value shows $\mathrm{mg} / \mathrm{g}$ dry flour basis. - : not detected.

flour substitution with or without $75 \mathrm{ppm}$ lipase (Fig. 2) and $\Delta h_{2}$ (Table 3), were observed, except for the case of $20 \%$ quinoa flour substitution with or without $75 \mathrm{ppm}$ lipase. Therefore, the increase in the $\Delta h_{2}$ was assumed to be derived from the characteristics of starch in the quinoa flour, and the $\Delta h_{2}$ might not be directly correlated with the staling of bread during storage.

\section{Effects of quinoa flour substitution and lipase} addition on the quantity of lipids in the dough.

The amount of free fatty acid in the dough after mixing for $20 \mathrm{~min}$ and $195 \mathrm{~min}$ in the home baker was determined (Table 4). In the control dough without quinoa flour substitution, the total amount of free fatty acid slightly increased when the mixing was increased from $20 \mathrm{~min}(1.48 \mathrm{mg} / \mathrm{g}$ dry 
flour) to $195 \mathrm{~min}(2.86 \mathrm{mg} / \mathrm{g}$ dry flour). On the other hand, in the $7.5 \%$ quinoa flour substitution, the total amount of free fatty acid decreased significantly when the mixing time was increased from $20 \mathrm{~min}(8.97 \mathrm{mg} / \mathrm{g}$ dry flour) to $195 \mathrm{~min}$ (4.60 mg/g dry flour). The decrease might be mainly due to the incorporation or inclusion of free fatty acids to the starch in dough during mixing and proofing. On the other hand, when 75 ppm lipase was added to the dough without quinoa flour substitution, the amount of free fatty acid in the dough did not change clearly when compared with the control. However, when 75 ppm lipase was added to the $7.5 \%$ quinoa flour substituted dough, the total amount of free fatty acid distinctly decreased compared with that without lipase, when the mixing time was $20 \mathrm{~min}$. Therefore, in the case of dough containing $7.5 \%$ quinoa flour and 75 ppm lipase, the free fatty acids liberated from lipids by the lipase might be adsorbed or attached to the dough, or incorporated into the helical portions of starch, which could not be easily extracted with $n$-hexane. In addition, lipoxygenase in the quinoa flour dough might be also involved in the degradation of lipids. However, further experiments are needed to make clear the effect of lipase on the lipids in the dough during mixing and proofing.

\section{SEM observation of bread dough.}

Wheat dough containing quinoa flour with or without lipase addition after mixing for $30 \mathrm{~min}$ in the home baker was observed by SEM (Fig. 4). The dough (B) containing 7.5\% quinoa flour showed an irregular gluten network structure and that (C) containing $20 \%$ quinoa flour showed a more irregular structure, that is, most gluten layers did not distribute continuously, and they surrounded the large starch granules as shown in (B) and $(\mathrm{C})$. The lipase-enhanced dough (E) showed a well-developed gluten network structure and the gluten covered each starch granule entirely. Therefore, the combined addition of $7.5 \%$ quinoa flour with $75 \mathrm{ppm}$ of lipase was tested as shown in F. The mixed dough showed that the well-developed gluten layers wrapped the starch granules more completely than in $\mathrm{B}$, and also large starch gran- ules are mostly covered with thick gluten layers. The quite small size of the starch granules (around $1 \mu \mathrm{m}$ in diameter) of quinoa flour might be helpful as a filling material in the gluten matrix. When $20 \%$ quinoa flour was used instead of $7.5 \%$ quinoa flour, the dough $(G)$ showed that the gluten appeared to become somewhat thinner, and to be scattered continuously around the starch granules in the dough.

Substitution of quinoa flour alone for wheat flour up to $10 \%$ improved the baking property, though it was only a slight effect. However, combining the quinoa flour with lipase distinctly improved the dough and baking properties. In fact, a combination of $15 \%$ quinoa flour and 75 ppm lipase distinctly improved the baking property of the dough compared with that of the control. The amount of $10 \%$ or $20 \%$ substitution of quinoa flour may not be low enough to avoid an allergenic reaction and it may not be enough to improve physiological activity significantly. Japanese consumers, unlike those in other advanced countries such as Europe and North America, do not like to eat whole-wheat bread. ${ }^{12)}$ So, even though the amount of substitution of quinoa flour for wheat flour is low, it is necessary to acquire the daily habit of eating bread made from flour mixed with pseudocereals, such as amaranth, buckwheat, millet, and so on.

In the present study, addition of lipase to wheat flour partially replaced with quinoa flour was found to improve breadmaking properties. We expect the quinoa flour or pseudocereals to be recognized as a functional foodstuff, and to be practically used for breadmaking as a partial substitution for wheat flour. Since quinoa flour contains high amounts of minerals, vitamins, dietary fibers, etc., these kinds of pseudocereals are needed to improve our daily diet patterns.

The authors wish to thank the Nisshin Flour Milling Co., Ltd. (Kobe) for supplying wheat flour; the Asai Co., Ltd. (Nagoya) for providing quinoa flour; the Asahi Kasei Co., Ltd. (Tokyo) for providing dry yeast; and the Amano Pharmaceutical Co., Ltd. (Nagoya) for providing lipase. They also thank Mr. T. Takao, the Dai-Nippon Meiji Sugar Co., Ltd. (Tokyo), for his valuable suggestions and comments on this study. 


\section{REFERENCES}

1 ) N.D. Vietmeyer: Lesser-known plants of potential use in agriculture and forestry. Science, 232, 1379-1384 (1986).

2 ) G.S. Ranhotra, J.A. Gelroth, B.K. Glaser, K.J. Lorenz and D.L. Johnson: Composition and protein nutritional quality of quinoa. Cereal Chem., 70, 303-305 (1993).

3 ) G.S. Chauhan, N.A.M. Eskin and R. Tkachuk: Nutrients and antinutrients in quinoa seed. Cereal Chem., 69, 85-88 (1992).

4 ) T. Takao: Component of quinoa and biological activity. Food Sci. J., 253, 52-58 (1999) (in Japanese).

5 ) N. Morita, Y. Arishima, N. Tanaka and T. Shiotsubo: Utilization of hemicellulase as bread improver in a home baker. J. Appl. Glycosci., 44, 143-152 (1997).

6 ) T. Maeda and N. Morita: Effect of polished-graded flour substitution to commonly milled wheat flour on the properties of dough and bread. J. Appl. Glycosci., 47, 1-12 (2000).

7 ) N. Inouchi, K. Nishi, S. Tanaka, M. Asai, Y. Kawase, Y. Hata, Y. Konishi, S. Yue and H. Fuwa: Characterization of amaranth and quinoa starches. J. Appl. Glycosci., 46, 233-240 (1999).

8 ) G.K. Gregory, T.-S. Chen and T. Philip: Quantitative analyses of carotenoid and carotenoid fatty acid esters in fruits by HPLC: Red bell peppers. J. Food Sci., 52, 1071-1073 (1987).

9 ) G.N. Jham, F.F.F. Teles and L.G. Campos: Use of aqueous $\mathrm{HCl} / \mathrm{MeOH}$ as esterification reagent for analysis of fatty acids derived from soybean lipids. $J$. Am. Oil Chem. Soc., 59, 132-133 (1982).

10) T.A. Siswoyo and N. Morita: Effect of phospholipids transesterified enzymatically with polyunsaturated fatty acid on gelatinization and retrogradation of starch. J. Nutr. Sci. Vitaminol., 46, 252-256 (2000).

11) K. Lorenz: Quinoa (Chenopodium quinoa) starchPhysico-chemical properties and functional character- istics. Starch/Stärke, 42, 81-86 (1990).

12) S. Ueki: Present situation of breadmaking in USA and its future in Japan. Rep. Jpn. Inst. Baking, 9-10, 3843 (2000) (in Japanese).

(Received August 30, 2000; Accepted January 12, 2001)

$$
\begin{gathered}
\text { ドウおよびパンの改良新食品素材 } \\
\text { としてのキノア粉 }
\end{gathered}
$$

森田尚文，平田智佳子，朴 商夏，光永俊郎 ${ }^{1}$

$$
\begin{gathered}
\text { 大阪府立大学大学院農学生命科学研究科 } \\
(599-8531 \text { 堺市学園町 1-1) }
\end{gathered}
$$

1 近畿大学農学部食品栄養学科・食品総合研究所

（631-8505 奈良市中町 3327-204）

新食品素材としてのキノア粉代替のドウおよび製パ ン特性についてレオメーター, ファリノグラフ, 示差 走査熱量計等により検討した。硬質小麦粉に 7.5-10\% のキノアを代替すると, パンの比容積は無添加のコン トロールよりも有意に増大したが, $15 \%$ 以上の添加で は明らかに減少した。しかしリパーゼ $75 \mathrm{ppm}$ (対粉当 り）と $15 \%$ キノアの代替により，その比容積は明らか に無添加のものより増大した。 パンのクラムはキノア の代替量の増加に伴い硬くなったが，リパーゼとの併 用により保存中の老化は抑制された．示差走查熱量測 定によりキノアの代替による澱粉の糊化温度および糊 化エンタルピー変化は無添加のものよりも明らかに大 きくなった. ドウの粘弾性についてはキノアとリパー ゼの併用により圧縮応力, 弾性率を減少させドウを軟 らかくするとともに吸水率および安定性を低下させる 傾向がみられた．以上，キノア粉の代替とリパーゼの 併用により製パン性を改良することが明らかとなった。 